\title{
Factors Affecting on Entrepreneurial Readiness of Vocational High School Students in Pacitan Regency
}

\author{
Azas Ramang Pambudi, Muhammad Nurtanto, Sulaeman Deni Ramdani, Nurcholish Arifin \\ Handoyono, Pramuda Ali Faizin \\ \{azasramang@gmail.com¹,mnurtanto23@untirta.ac.id², s.deni.ramdani@untirta.ac.id ${ }^{3}$, \\ ariph7@gmail.com ${ }^{4}$, praalifaizin@gmail.com $\left.{ }^{5}\right\}$
}

Technology and Vocational Education Graduate Student, Graduate School Of Yogyakarta State University, Yogyakarta, Indonesia ${ }^{1}$, Mechanical Engineering Education Department, Teacher Training and Education Science Faculty of Sultan Ageng Tirtayasa University ${ }^{2,3}$, Mechanical Engineering, Education Department, Teacher Training and Education Science Faculty of Taman Siswa University, Yogyakarta, Indonesia ${ }^{4}$, Accounting Department, Ngadirojo State Vocational High School, Pacitan,

$$
\text { Indonesia }{ }^{5}
$$

\begin{abstract}
This study aims to reveal the influence, both individually or collectively, entrepreneurial motivation, entrepreneurial knowledge, vocational guidance and family support on entrepreneurial readiness of vocational high school student's in Pacitan regency. This research was expost-facto, conducted in five vocational high school in Pacitan regency. The research population was the third grade students of vocational high school automotive program. It has been found that entrepreneurial motivation, entrepreneurial knowledge, vocational guidance and family support individually have significant effect on entrepreneurial readiness. Moreover, entrepreneurial motivation, entrepreneurial knowledge, vocational guidance and family support also collectively have significant effect on entrepreneurial readiness. This finding has both theoretical and practical implications for entrepreneurial area in vocational high school.
\end{abstract}

Keywords: entrepreneurship, vocational high school, Pacitan.

\section{Introduction}

The world of entrepreneurship in the automotive field and other fields becoming its derivatives has a great potential for people's lives. [1] states, "It created job opportunities, raised living standards, reduced poverty, created entrepreneurial opportunities." The automotive sector contributes to the creation of job opportunities, improve living standards, reduce poverty and create entrepreneurial opportunities. The growth and success of the automotive industry has a positive influence on the social progress of society. Trends in the automotive sector that are constantly changing contribute to the development of entrepreneurship in the automotive sector to continue to grow.

The automotive sector is one of the largest vocational expertise programs with specialization in Pacitan district. According to the basic data of Vocational Schools from the Directorate of Vocational High School Development, it was recorded that in 2016/2017 there were 22 Vocational High Schools (SMK) providing automotive expertise programs. Of the 22 Vocational High School, the number of students in grade XII of the automotive expertise 
program has 722 students or $21.82 \%$ of 3309 students. This figure is the second highest number of all grade students of XII SMK in Pacitan under the Computer and Informatics expertise program with 746 or $22.54 \%$ students.

The fact that automotive is one of the expertise programs with the largest number of students is an encouraging news for the development of the automotive entrepreneurship sector in Pacitan. Graduates from the automotive department will make a potential contribution to human resources in the sector. As is known, vocational high school graduates can reach three areas of establishing their own businesses or entrepreneurship, working as employees and continuing to higher education. However, based on the results of a preliminary study conducted by researcher at PGRI Ngadirojo Private Vocational High School (SMKS PGRI Ngadirojo) and 1st Donorojo State Vocational High School (SMK Negeri 1 Donorojo), the students who graduated from automotive expertise programs who decided to become entrepreneurs had a small percentage. According to the data from graduates of SMKS PGRI Ngadirojo, as many as 4 out of 81 students graduating from the Department of Light Vehicle Engineering went through the entrepreneurial profession. Whereas, from the data of graduates of SMK Negeri 1 Donorojo, there are no graduates who eager to become entrepreneur. Based on the graduates' tracking data, it is known that there are no graduates who have undergone an entrepreneurial profession in the automotive field or in accordance to their educational background.

The majority of graduates in that year chose to work as employees, then a small percentage went on to higher education. Whereas the rest of the career development has not been known after graduating from school. Another fact obtained during the presurvey activity is the lack of enthusiasm of students for entrepreneurship after graduating from school. Through informal conversations conducted with grade XII students, researcher gained recognition that according to students entrepreneurship requires a lot of capital that is difficult to reach.

Students feel that entrepreneurship requires a lot of experience, which according to the students they do not yet have so that makes them feel insecure to direct entrepreneurship. Eventually working for others as employees is the preference of the majority of students after graduating from school. Considering the reality above, vocational education graduates are perceived as not showing mental and personal as is the goal of vocational education.

Another problem encountered during prasurvey and considered to be potential obstacles to student entrepreneurship readiness is the implementation of industrial work practices (prakerin) that have not been maximized. According to the information from the productive teacher of Light Vehicle Engineering program (Teknik Kendaraan Ringan/TKR) in the Vocational School, the disciplinary factor of the students was the biggest proponent during the implementation of the internship program. Another acknowledgment from the students explained that, they felt dissatisfied with the implementation of the apprenticeship that they were living on the grounds of the lack of direction and assistance provided by skilled workers in workplace (DUDI) to students.

Entrepreneurship as a career choice is often a marginalized choice. Mentoring program services in schools tend to be academically charged and lack attention to values, attitudes, knowledge and skills in vocational fields [2]. This is often reinforced by the provision of information that tends to direct students to take career paths as employees rather than entrepreneurship. Likewise with entrepreneurship, as one of the choices in a career, this is often only as an urgent policy to address issues related to unemployment and weakening of a country's economic conditions. 
Law number 20 of 2003 states that there are four guidance and counseling services in every primary and secondary education institution in Indonesia, including in Vocational Schools. One of these services is career guidance or vocational guidance. Vocational guidance is intended to prepare for the future of students 'careers by increasing students' self-adjustment in vocational fields as an effort to facilitate the transition to the world of work [3]. This is important considering that there are still doubts about the abilities and skills possessed by vocational students during their education [4].

Empirical facts found during the prasurvey research, it was found that the implementation of vocational guidance in vocational schools had not been implemented properly. Guidance in schools still focuses on counseling guidance that focuses on students with moral and behavioral problems. In addition, it was found that there was no special assignment to guidance teachers for each of the four service areas. Each guidance teacher has the authority to handle all forms of services. Such a system makes vocational guidance tend to be marginalized, where guidance teachers will spend a lot of time on other service areas and vocational content in student career decision making will become blurred and tend to be educational decisions [5].

Instead of through vocational guidance in school, career orientation and the world of work can be obtained by students through the family environment. This is emphasized by the opinion of [6] that there are at least three reasons for how families influence the growth of individual entrepreneurial souls. According to Hoffman et al, individuals from families with entrepreneurial backgrounds have a greater likelihood of doing entrepreneurial activities because the parents' business will be passed on to the child. Individuals who grow in an entrepreneurial family environment, according to Hofman et al, will have superior entrepreneurial human capital compared to others. The profession of parents as entrepreneurs becomes role models for children and also influences their career choice preferences.

Globalization is no longer a necessity but has become a reality that must be faced. The emergence of globalization creates a number of opportunities and challenges. Its existence has made the boundary between countries increasingly false, so that each country is connected to each other more easily. However, this has also helped these countries to estuary competition in every sector of life. Therefore, every country must hurry to prepare themselves to win the competition, one of which is by providing quality human resources in the form of skilled workforce. [7] states that knowledge; education and experienced workforce are the most valuable human capital in the global era. In accordance with the mandate of Law 202003 the task is charged to vocational schools as vocational institutions at the level of secondary education that have the obligation to produce ready-to-use labor graduates.

\section{Theoretical Review}

Vocational education is a special education for those who have an interest in preparing themselves to work in certain fields. Various terms are used in various countries to represent educational programs ready for work. Regarding the various terms, Wenrich and Galloway [8] stated, the use of various terms that refer to vocational education represents something identical, referring to the similarity of understanding that is about education ready to work.

The basic concept of entrepreneurship readiness is an important step in this study. Measuring entrepreneurship readiness will be very difficult without first determining the concept underlying this as a reference. For this reason, this study will adopt the statement of 
[9] as the basic concept, "Entrepreneurs need to possess competencies to perform entrepreneur activities". The statement above implies that an entrepreneur does not only limit himself to certain fields of science, but needs to equip himself with everything that can support his entrepreneurial activities.

Motivation moves someone to achieve the desired goal. Motivation provides energy to one's behavior to lead to a specific goal as desired. "Motivation is the process used to allocate energy to maximize the satisfaction of needs" [10]. Motivation is a process of providing energy to maximize satisfaction of needs. Needs cause turmoil in a person and then become a trigger in taking action as an effort to meet those needs.

Knowledge is one of the provisions that must be possessed by every entrepreneurial profession. [11] states that knowledge gained during education and training is the most important investment in human capital. Entrepreneurial capital in the form of human capital or human capital is an important source in the success of entrepreneurship [12]. According to [13] human capital is recognized as a stepping stone to developing social networks which are also at the same time determining the success of an entrepreneurial activity. [14] even stated that human capital also has a strong influence on individual income development.

Vocational guidance helps students to grow and develop their abilities. [15] argues that there are three factors in determining career choices, including: (a) profound selfunderstanding; (b) knowledge to achieve success; (c) consideration of the conditions of the two previous factors. The success of individuals in achieving success is the result of a combination of ability and enthusiasm with everyday life experiences. Therefore, individuals need to explore themselves to determine their capacities, interests, resources and at the same time the shortcomings that cause them to compare their talents, abilities and ambitions with success demands in every career field.

Vocational guidance support for entrepreneurship learning has an important role in developing entrepreneurial skills. Recognition of the importance of the combination of vocational education and vocational guidance in schools is increasing, not only in helping students to make choices about their careers but also in laying the foundation for their career development [16]. This combination can provide awareness, exploration initiatives, and the development of a person's management skills that are useful not only limited to the interests of the position or task but for the future of the career as a whole.

The family is the main environment of individuals, where individuals enter adolescence, the family becomes an environment where individuals spend the most time. [17] stated, "From birth through adolescence, the family is responsible for socializing the child. The family environment is responsible for the individual's social life from birth to adolescence. Families also become the main environment for the process of planting values and norms by parents or other family members to children. Therefore, families play an important role in individual career development stages.

\section{Research Method}

This research is a study of the effect of entrepreneurial motivation, entrepreneurial knowledge, students 'perceptions of vocational guidance, and students' perceptions of family support for entrepreneurial readiness of vocational students in grade XII of the automotive expertise program in Pacitan. The study aimed to reveal the magnitude of the influence of entrepreneurial motivation, entrepreneurship knowledge, vocational guidance, and family 
support for entrepreneurial readiness of vocational students grade XII of automotive expertise programs in Pacitan regency. The type of research used is expost facto research. This research is a non-experimental study which means that researcher do not give treatment to the variables that will be studied.

The research was carried out in five public and private Vocational Schools in the Pacitan Regency region which organized automotive expertise programs. The five vocational schools referred to in the study were 3rd Pacitan State Vocational High School (SMKN 3 Pacitan), PGRI Ngadirojo Private Vocational High School (SMKS PGRI Ngadirojo), Bina Karya Private Vocational High School (SMKS Bina Karya), 1st Donorojo State Vocational High School (SMKN 1 Donorojo) dan 1st PGRI Pacitan Private Vocational High School (SMKS PGRI 1 Pacitan). The research was conducted in June 2017 - July 2017.

The research subjects were all students of grade XII of the Automotive Expertise Program in five SMK. The study population was 256 students. Based on the [18], the researcher obtained a certainty of a sample of 153.87. The sample figures calculated from each school are rounded. As stated by Sugiyono [19], the number of samples getting closer to the number of population is getting better. Based on these rules, the number of research samples was 157 students.

Table 1. Population and Research Sample

\begin{tabular}{lccc}
\hline \multicolumn{1}{c}{ School name } & Population & \multicolumn{2}{c}{ Sampel } \\
Number & Number rounding \\
\hline SMKS PGRI Ngadirojo & 57 & 34,289 & 35 \\
SMKN 3 Pacitan & 30 & 18,047 & 19 \\
SMKN 1 Donorojo & 88 & 52,937 & 53 \\
SMKS 1 PGRI Pacitan & 32 & 19,250 & 20 \\
SMKS Bina Karya & 49 & 29,477 & 30 \\
Jumlah & 256 & 154 & 157 \\
\hline
\end{tabular}

\section{Research Result And Discussion}

\subsection{Research Result}

The results of a sample of 157 students of the Automotive Engineering Expertise Program in Vocational Schools in Pacitan in grade XII which were proportionally distributed at the 5\% error level are as follows:

\subsection{Enterprenaurial Motivation}

Questionnaire items on entrepreneurial motivation instruments consist of 29 valid and reliable statements. The results of the student entrepreneurship motivation variable are $23.57 \%$ or 37 out of 157 students have very high motivation for entrepreneurship; $29.94 \%$ or 47 of 157 students have high motivation for entrepreneurship; $23.57 \%$ or 37 of 157 students have low motivation for entrepreneurship; and $22.93 \%$ or 36 of 157 students have very low motivation for entrepreneurship. 


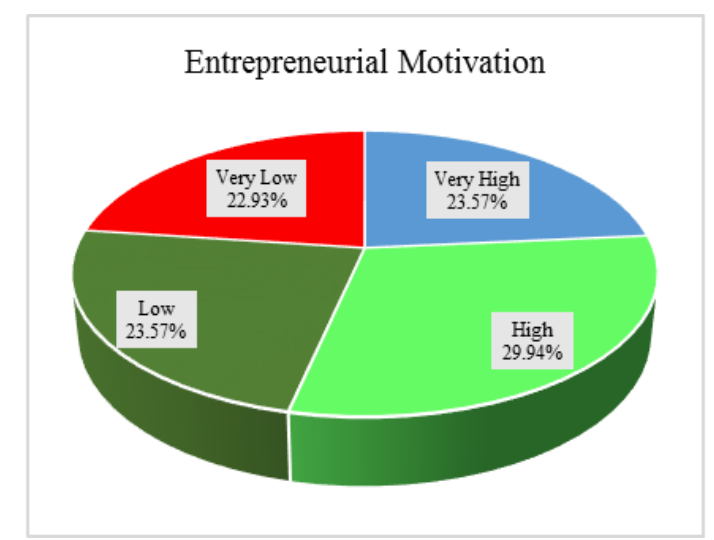

Fig. 1. Enterpreneurial Motivation Description Data

\subsection{Enterpreneurial Knowledge}

Multiple choice questions on the entrepreneurial knowledge instrument consist of 36 questions. The description of the results of student entrepreneurship knowledge variables is $19.75 \%$ or 31 of 157 students have an understanding of entrepreneurial knowledge is very high; $33.76 \%$ or 53 of 157 students have an understanding of high entrepreneurial knowledge, $27.39 \%$ or 43 of 157 students have an understanding of low entrepreneurial knowledge, $19.11 \%$ or 30 of 157 students have very low understanding of entrepreneurial knowledge. Based on the description of the test results above students have a high tendency of entrepreneurial knowledge.

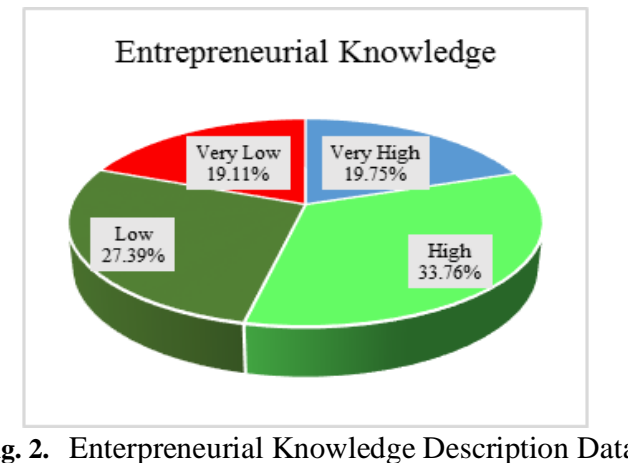

\subsection{Vocational Guidance}

Questionnaire items on vocational guidance instruments consist of 17 statements. The description of the results of the variable vocational guidance is $15.92 \%$ or 25 of 157 students argue that vocational guidance services in relation to student careers are very high; $27.39 \%$ or 43 of 157 students found that vocational guidance services related to career students were high, $36.31 \%$ or 57 out of 157 students thought that vocational guidance services related to career students were low, $20.38 \%$ or 32 out of 157 students argued that vocational guidance services related to student careers are very low. Based on the description above, students have a perception that services from vocational guidance programs are low. 


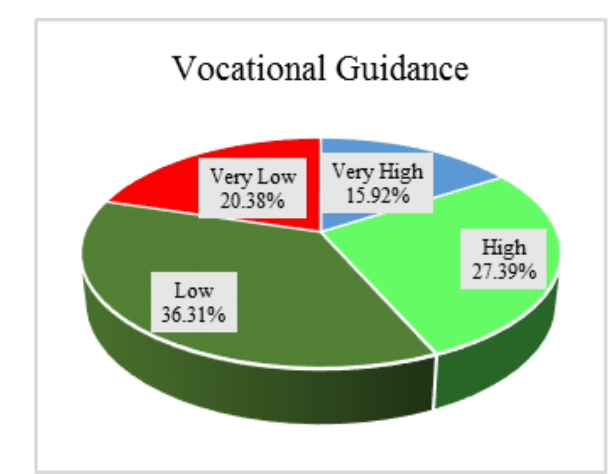

Fig. 3. Vocational Guidance Description Data

\subsection{Family Support}

Questionnaire items on family support instruments consist of 12 statements. The results of the family support variables are $24.2 \%$ or 38 of 157 students argue that family support has a very high influence in relation to students' career sustainability; $32.48 \%$ or 51 of 157 students argue that family support has a high influence in relation to students' career sustainability; $21.66 \%$ or 34 of 157 students argue that family support has a low influence in relation to students' career sustainability; $21.66 \%$ or 34 out of 157 students argue that family support has a very low influence in relation to students' career sustainability. Based on the elaboration of all the results of the above research it can be concluded that students' perceptions of family support are included in the high category.

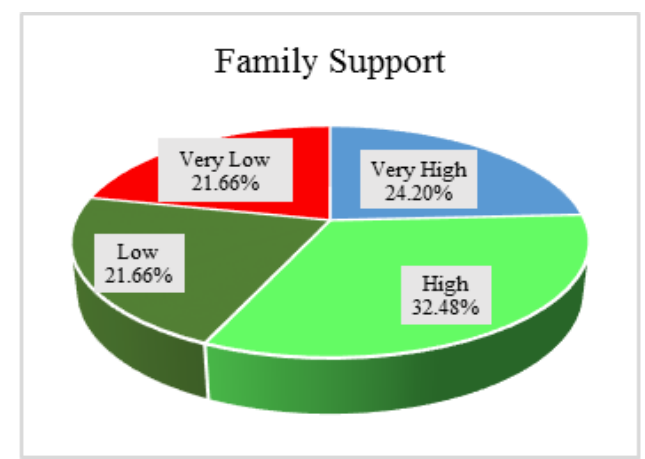

Fig. 4. Family Support Description Data

\subsection{Enterpreneurial Readiness}

Questionnaire items on the instrument of entrepreneurship readiness consist of 19 statements. The description of the results of the variable entrepreneurship readiness is $13.38 \%$ or 21 of 157 students have very high entrepreneurship readiness; $22.93 \%$ or 36 of 157 students have high entrepreneurial readiness; $33.76 \%$ or 53 of 157 students have low entrepreneurial readiness; $29.94 \%$ or 47 out of 157 students have very low entrepreneurship readiness. Based on the description above, it is known that students' entrepreneurship readiness is low. 


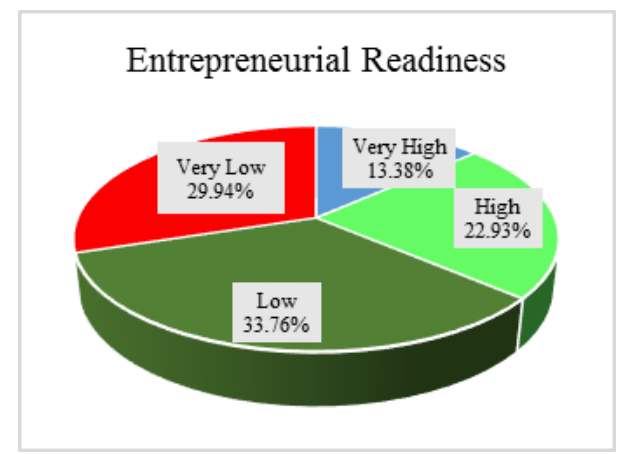

Fig. 5. Enterpreneurial Readiness Description Data

\subsection{Multiple Linear Regression Assumptions Test}

\section{Normality Test}

The normality test of the results of the research was carried out by using the KolmogorovSmirnov One-Sample test. The normality test performed obtained the following results:

\begin{tabular}{ccc}
\multicolumn{3}{c}{ Table 2.The Result of Normality Test } \\
\hline Variable & Asymp. Sig & Result \\
\hline X1 & 0,310 & Normal \\
X2 & 0,604 & Normal \\
X3 & 0,630 & Normal \\
X4 & 0,692 & Normal \\
Y & 0,859 & Normal \\
\hline
\end{tabular}

The above table shows that the Asymp value. The Sig of the five research variables is greater than 0.05 . Therefore, from this explanation, it can be concluded that the distribution of data from the five research variables used is included in the normal category.

\section{Linearity Test}

Linearity test was done to determine the linearity of the relationships between data from independent variables with the dependent variable. Linearity test is done by the test for linearity method. The linearity test performed obtained the following results:

Table 3. Linearity Test Result

\begin{tabular}{ccc}
\hline Variable & Linierity & Deviation from Linierity \\
\hline $\mathrm{X} 1-\mathrm{Y}$ & 0,000 & 0,373 \\
$\mathrm{X} 2-\mathrm{Y}$ & 0,000 & 0,507 \\
$\mathrm{X} 3-\mathrm{Y}$ & 0,000 & 0,101 \\
$\mathrm{X} 4-\mathrm{Y}$ & 0,000 & 0,526 \\
\hline
\end{tabular}

From the above table, it can be explained that of the four relationships of independent variables and dependent variables obtained linearity values of less than 0.005 . In addition, the deviation from linearity of the dependent variable with each independent variable is more than 0.05. Based on this result, it was concluded that the independent variable had a linear relationship with the student entrepreneurship readiness variable as the dependent variable in the research. 


\section{Multicollinearity Test}

Multicollinearity test was conducted to determine whether there is a high correlation between independent variables by looking for the value of Variance Inflation Factor (VIF). The multicollinearity test performed obtained the following results:

\begin{tabular}{ccc}
\multicolumn{4}{c}{ Table 4. Multocollinearity Test Result } \\
\hline Variable & Tolerance & VIF \\
\hline X1 & 0,526 & 1,900 \\
X2 & 0,530 & 1,886 \\
X3 & 0,390 & 2,564 \\
X4 & 0,350 & 2,854 \\
\hline
\end{tabular}

Based on the above table, four independent variables have a VIF value of less than 10, with the largest VIF value being 2.854 , which is the VIF value of the family support variable. The table above also shows that the tolerance value of the four independent variables is more than 0.10 or greater than the minimum tolerance value required. From the description, it can be concluded that the four independent variables used in the study there is no multicollinearity relationship.

\section{Homosedasticity Test}

Homosedasticity test was done with the aim to see the overall correlation between independent variables and dependent variables. The expected result of this test is that the data has the same variance or homosedasticity. Homosedasticity test performed obtained the following results:

\begin{tabular}{ccc}
\multicolumn{3}{c}{ Table 5. Homosedaticity Test Result } \\
\hline Variable & Sig. & Result \\
\hline X1 & 0,540 & Homogen \\
X2 & 0,211 & Homogen \\
X3 & 0,884 & Homogen \\
X4 & 0,230 & Homogen \\
\hline
\end{tabular}

The data presented in table 4.9. above shows that the value of sig. of the four independent variables greater than 0.05 . The explanation shows that the data from the four independent variables of the study are homogeneous data and there is no symptom of heteroscedasticity, so the preconditions of homosedasticity of data before carrying out the main stages of testing through regression tests have been fulfilled.

\subsection{Multiple Liniear Regression Test}

Prerequisite tests that have been carried out give results that the research data meets the requirements for multiple regression tests. Multiple linear regression tests performed obtained the following results: 
Table 6. Multiple Liniear Regression Test Result

\begin{tabular}{|c|c|c|c|c|c|c|}
\hline \multirow{2}{*}{\multicolumn{2}{|c|}{ Model }} & \multicolumn{2}{|c|}{$\begin{array}{c}\text { Unstand. } \\
\text { Coefficients }\end{array}$} & \multirow{2}{*}{$\begin{array}{c}\begin{array}{c}\text { Stand. } \\
\text { Coefficients }\end{array} \\
\text { Beta }\end{array}$} & \multirow[t]{2}{*}{$\mathrm{t}$} & \multirow[t]{2}{*}{ Sig. } \\
\hline & & B & Std. Error & & & \\
\hline & (Constant) & 1.132 & 2.365 & & .479 & .633 \\
\hline & Enterpreneurial Motivation & .193 & .038 & .296 & 5.008 & .000 \\
\hline & Enterpreneurial Knowledge & .359 & .095 & .223 & 3.783 & .000 \\
\hline & \begin{tabular}{|l|l} 
Vocational Guidance \\
\end{tabular} & .309 & .080 & .265 & 3.863 & .000 \\
\hline & Family Support & .301 & .101 & .216 & 2.988 & .003 \\
\hline
\end{tabular}

a. Dependent Variable: Enterpreneurial Readiness

The results of multiple regression values were used to find the percentage of the effective contribution and the relative contribution of the independent variable to the dependent variable. The percentage of the contribution value of each independent variable to the dependent variable is presented in the table as follows:

Table 7. The Value of Effective and Relative Contribution

\begin{tabular}{ccc}
\hline Variabel & Effective Contribution & Relative Contribution \\
\hline $\mathrm{X} 1-\mathrm{Y}$ & $21.37 \%$ & $29.61 \%$ \\
$\mathrm{X} 2-\mathrm{Y}$ & $15.27 \%$ & $21.16 \%$ \\
$\mathrm{X} 3-\mathrm{Y}$ & $19.51 \%$ & $27.03 \%$ \\
$\mathrm{X} 4-\mathrm{Y}$ & $16.02 \%$ & $22.20 \%$ \\
Total & $72.17 \%$ & $100 \%$ \\
\hline
\end{tabular}

Based on the table above the independent variable contributes to the influence of the dependent variable in a total of $72.17 \%$. Entrepreneurial motivation contributes $21.37 \%$. This figure is the biggest percentage, which means that the entrepreneurship motivation variable has the greatest influence on student entrepreneurship readiness. Entrepreneurial knowledge contributes to the influence of $15.27 \%$. This percentage is the smallest, signifying entrepreneurial knowledge contributing to the smallest influence on student entrepreneurship readiness. Vocational guidance contributes to the influence of student entrepreneurship readiness by $19.51 \%$. While family support contributes to students' entrepreneurial readiness $16.02 \%$

\section{Discussion}

\subsection{The effect of enterpreneurial motivation (X1) on students enterpreneurial readiness (Y)}

Based on the results of regression analysis it is known that entrepreneurial motivation has a positive and significant effect on student entrepreneurship readiness based on the Standardized Coefficients Beta value $(\beta)$ of 0.193 and a significance value of 0.000 . The acquisition of the research data rejects the null hypothesis and accepts the alternative hypothesis. Thus, there is a positive and significant effect of entrepreneurial motivation on entrepreneurial readiness of vocational students in grade XII of the automotive expertise program in Pacitan.

Building a new business is a decision that is heavily influenced by personal initiatives. [20] stated that motivation to start a business is one of the keys to starting a business. 
Motivation is influential in every transition at the stage of the entrepreneurship process which starts from reading a business opportunity and is followed by the development of how to realize the opportunity, evaluation, product or service development to be provided, assembling human and financial resources, forming an organization, and looking for consumers [21]. Shane et al also argued that motivation can influence aspects of individual behavior so that it will indirectly affect entrepreneurship activities.

According to research conducted by [22] there are several motivations that are generally accepted in developing countries, among others, seeking greater achievement in the business (greater business achievement), independence (intrinsicfactor) and comfort work (job security). Stefanovic et al also revealed that individual participation in entrepreneurship in developing countries is dominated by short-term motives compared to long term motives. This is because the main motivation of entrepreneurs in developing countries is to survive and guarantee the survival of their lives and their families.

\subsection{The effect of enterpreneurial knowledge (X2) on students enterpreneurial readiness} (Y)

Based on the results of regression analysis, it is known that entrepreneurial knowledge has a positive and significant effect on student entrepreneurship readiness based on the Standardized Coefficients Beta value $(\beta)$ of 0.359 and a significance value of 0.000 . The acquisition of the research data rejects the null hypothesis and accepts the alternative hypothesis. Thus, there is a positive and significant effect of entrepreneurial knowledge on entrepreneurial readiness of vocational students.

Undergoing formal education is an important input for social, professional and individual personality development. Through his research, [23] underlines the aspects of attitudes, norms and behavior of students that will be formed positively after gaining entrepreneurial education experience at school. Students who view entrepreneurship education positively will also have positive subjective attitudes and norms as well as better behavioral control that can lead students to the intention of entrepreneurship. Schools on the one hand are educational institutions that still focus on developing students' cognitive knowledge, but on the other hand it is also a social community that is a place for exchanging various forms of values and information in them. The diversity of values and information that every school citizen has, which then exchanges, also adds to the scientific repertoire that is received by every school member in it, especially students.

Applying a learning approach that is more prominent on the practical side [24] and equipping teachers with the most current and reliable knowledge (Hannon, 2007) can be the right solution to improve students' entrepreneurship experience. Establishing a business and developing it to an established position requires a short period of time. Therefore, only encouraging students to undergo an entrepreneurship career without providing them with relevant knowledge and skills is inappropriate.

\subsection{The effect of vocational guidance $(\mathrm{X} 3)$ on students enterpreneurial readiness $(\mathrm{Y})$}

Based on the results of regression analysis, it is known that vocational guidance has a positive and significant effect on student entrepreneurship readiness based on the Standardized Coefficients Beta value $(\beta)$ of 0.309 and a significance value of 0.000 . The acquisition of the research data rejects the null hypothesis and accepts the alternative hypothesis. Thus, there is a 
positive and significant effect of vocational guidance on entrepreneurship readiness of vocational students.

Stated that vocational guidance is a medium that bridges schools with the world of work through the programs they organize [25]. Provision of vocational career information, which is one of the main vocational guidance services, supports the advancement of students' insight and knowledge in finding business opportunities that are in line with their potential and talents. Education and vocational guidance must be an integral part of the overall provision of education that provides understanding to students for the relationship between what they learned and their next professional career.

\subsection{The effect of family support $(\mathrm{X} 4)$ on students enterpreneurial readiness $(\mathrm{Y})$}

Based on the results of regression analysis it is known that family support has a positive and significant effect on student entrepreneurship readiness based on the Standardized Coefficients Beta value $(\beta)$ of 0.301 and a significance value of 0.000 . The acquisition of the research data rejects the null hypothesis and accepts the alternative hypothesis. Thus, there is a positive and significant effect of family support on entrepreneurship readiness of vocational students.

Family is one of the factors that influence the development of one's entrepreneurial culture and attitudes [26]. The family environment is the initial environment that shapes individual attitudes and personalities. Parenting patterns and education applied in the family influence the formation of student character. Description of research results shows that family support variables have a high tendency. This indicates that students' perceptions regarding the role of family support tend to be positive overall. According to [27] students who have extensive networking capital show higher intentions in entrepreneurship as their career choice.

Early life experiences play an important role in creating one's attitudes, personality and intentions. Related to this, [28] argued, individuals who grow up in an entrepreneurial family environment share the experience of entrepreneurship in the form of challenges and opportunities that encounter family businesses. Experience for the experience gained by an individual makes him feel familiar and trained in the situation.

\subsection{The effect of enterpreneurial motivation (X1), enterpreneurial knowledge (X2), vocational guidance $(\mathrm{X3})$, family support $(\mathrm{X} 4)$ simultaneously on enterpreneurial readiness $(\mathbf{Y})$}

Based on the results of the research and testing hypotheses obtained results that stated reject Ho (null hypothesis) and thus Ha (alternative hypothesis) proposed was accepted. These results can also be interpreted to have a positive and significant effect between entrepreneurial motivation, entrepreneurship knowledge, vocational guidance and family support for entrepreneurial readiness of grade XII SMK students. The acceptance of the alternative hypothesis is based on the results of the calculation of the statistical research data that produces the R Square (R2) number of 0.721. This figure implies that student entrepreneurship readiness is influenced by $72.1 \%$ with biggest contribution given by entrepreneurial motivation variable of $21.37 \%$, while smallest contribution given by entrepreneurial knowledge variable of $15.27 \%$. 


\section{Conclusion}

Based on the results of research and discussion, the following conclusions are obtained:

1 There is positive and significant effects of the four independent variables, partially or collectively, on entrepreneurial readiness as dependent variable.

2 Based on the R Square value, it can be seen that the four independent variables have an effect of $72.1 \%$ on entrepreneurial readiness; while the other $27.9 \%$ is influenced by other variables not examined. According the percentage percentage of influence of $72.1 \%$, the biggest contribution was given by the variable of entrepreneurship motivation with a percentage value of $21.37 \%$, while the variable with the smallest contribution of influence was entrepreneurial knowledge with a percentage of $15.27 \%$.

Acknowledgements. The authors would like to thank Professor Sunarto from Graduate School of Yogyakarta State University, and Dr. Edy Supriady as reviewer for insightful suggestions. Moreover, the authors give best thanks to everyone for the kind help during the production process.

\section{References}

[1] S. [1] Abdullah, "The transformation from entrepreneurship to technology entrepreneurship development in Malaysia: State-led initiatives.," J. Chinese Entrep., vol. 1, pp. 240-247, 2009.

[2] A. G. [27] Watts, The relationship of career guidance to VET. Cambridge: National Institute for Careers Education and Counselling (OECD Report)., 2009.

[3] D. E. [22] Super, "Transition: from vocational guidance to counseling psychology," J. Couns. Psychol., vol. 2, p. 3, 1955.

[4] S. [4] Billett, "Changing work, work practice: The consequences for vocational education," in International handbook of education for the changing world of work., Springer, Dordrecht, 2009, pp. $175-187$.

[5] and R. G. S. [29] Watts, Anthony Gordon, "Career guidance policies in 37 countries: Contrasts and common themes," Int. J. Educ. Vocat. Guid., vol. 4, p. 105-122., 2004.

[6] and N. M.-M. [9] Hoffmann, Anders, Martin Junge, "Running in the family: parental role models in entrepreneurship,” Small Bus. Econ., vol. 44, pp. 79-104, 2015.

[7] and H.-P. B. [11] Mills, Melinda, "Globalization, uncertainty and the early life course. A theoretical framework: Melinda Mills and Hans-Peter Blossfeld.," Glob. Uncertain. youth Soc., pp. 31-53, 2006.

[8] S. [23] Dharma, Tantangan guru SMK abad 21. jakarta: Direktorat Pembinaan Pendidik dan Tenaga Kependidikan Pendidikan Menengah, Direktorat Jenderal Pendidikan Menengah, Kementerian Pendidikan dan Kebudayaan, 2013.

[9] V. [26] Havinal, Management and entrepreneurship. New Age International, 2009.

[10] and E. A. [16] Pritchard, Robert, "Managing motivation: A manager's guide to diagnosing and improving motivation," 2008.

[11] G. S. [3] Becker, Human Capital: A Theoretical and Empirical Analysis, with Special Reference to Education. Chicago: University of Chicago Press., 1994.

[12] et al [25] Unger, Jens M., "Human capital and entrepreneurial success: A meta-analytical review," J. Bus. Ventur., vol. 26, pp. 341-358, 2011.

[13] and M. W. [12] Mosey, Simon, "From human capital to social capital: A longitudinal study of technology-based academic entrepreneurs," Entrep. theory Pract., vol. 31, pp. 909-935, 2007.

[14] and A. H. R. [20] Stroh, Linda K., Jeanne M. Brett, "All the right stuff: A comparison of female and male managers' career progression,” J. Appl. Psychol., vol. 77, p. 251, 1992.

[15] F. [14] Parsons, Choosing a vocation. Houghton Mifflin. 
[16] and D. H. F. [28] Watts, Anthony G., "Public Policies for Career Development. Case Studies And Emerging Issues For Designing Career Information And Guidance Systems In Developing And Transition Economies," in World Bank Education Advisory Service, 2004.

[17] and D. J. M. [7] Delamater, J. D., Social Psychology , Wadsworth, a division of Thomson Learning. 2007.

[18] W. G. [6] Cochran, Sampling Techniques, 3d Ed. New York: Wiley, 1977.

[19] D. [21] Bandung, Metode Penelitian Pendidikan Pendekatan Kuantitatif, Kualitatif dan R \& D. Bandung: Alfabeta, 2013.

[20] and C. A. S. [2] Sánchez, Virginia Barba, "Entrepreneurial behavior: Impact of motivation factors on decision to create a new venture," Investig. Eur. Dir. y Econ. la Empres., vol. 18, pp. 132 $138,2012$.

[21] and C. J. C. [17] Shane, Scott, Edwin A. Locke, "Entrepreneurial motivation," Hum. Resour. Manag. Rev., vol. 13, pp. 257-279, 2003.

[22] and L. R. [19] Stefanovic, Ivan, Sloboda Prokic, "Motivational and success factors of entrepreneurs: the evidence from a developing country," in Zbornik radova Ekonomskog fakulteta u Rijeci/Proceedings of Rijeka Faculty of Economics, 2010, p. 251-269.

[23] M. C. [10] Sondari, "Is entrepreneurship education really needed?: Examining the antecedent of entrepreneurial career intention.," Procedia-Social Behav. Sci., vol. 115, p. 44-53., 2014.

[24] S. P. [13] Nkirina, "The challenges of integrating entrepreneurship education in the vocational training system: An insight from Tanzania's Vocational Education Training Authority,” J. Eur. Ind. Train., vol. 34, pp. 153-166, 2010.

[25] and B. H. [8] Borgen, William, "Understanding the context of technical and vocational education and training," Tech. Vocat. Educ. Train. 21 st Century, 2002.

[26] J. [15] Potter, "Entrepreneurship and higher education: future policy directions," Local Econ. Employ. Dev., pp. 313-335, 2008.

[27] L. [18] Sharma, "Impact of family capital \& social capital on youth entrepreneurship-a study of Uttarakhand state, India,” J. Glob. Entrep. Res., vol. 4, p. 14, 2014.

[28] and J. M. S. [5] Carr, Jon C., "Prior family business exposure as intergenerational influence and entrepreneurial intent: A theory of planned behavior approach.,” J. Bus. Res., vol. 60, pp. 1090-1098, 2007. 